\title{
GENDER: INTEGRATING CRIMES AGAINST WOMEN INTO INTERNATIONAL CRIMINAL LAW
}

\author{
Mohammad Irfan \\ International Islamic University Malaysia \\ Moh.irfan@gmail.com
}

\begin{abstract}
The author identifies the major goals and achievements in the area of recognizing women as full subjects of human rights and eliminating impunity for gender crimes, highlighting the role of nongovernmental organizations ("NGO's"). Until the 1990 s sexual violence in war was largely invisible, a point illustrated by examples of the "comfort women" in Japan during the 1930s and 1940s and the initial failure to prosecute rape and sexual violence in the ad hoc international criminal tribunals for the former Yugoslavia and Rwanda. Due in a significant measure to the interventions by NGOs, the ad hoc international criminal tribunals have brought gender into mainstream international jurisprudence. For example, the Yugoslavia tribunal has devoted substantial resources to the prosecution of rape and explicitly recognized rape as torture, while the Rwanda tribunal has recognized rape as an act of genocide. Elsewhere, the Statute of the International Criminal Court is a landmark in codifying not only crimes of sexual and gender violence as part of the ICC's jurisdiction, but also in establishing procedures to ensure that these crimes and their victims are properly treated. Working towards this end the Women's Caucus for Gender Justice met with significant opposition. It persisted because of the imperative that sexual violence be seen as part of already recognized forms of violence, such as torture and genocide.
\end{abstract}

Keyword: Gender, Crimes Against Women, International Criminal Law.

\section{A. INTRODUCTION}

The Women's Caucus for Gender Justice is also heir to a process of women's caucuses, each one created in relation to the recent series of UN conferences to introduce the issue of women and gender. The first task was to write women into human rights at the 1993 Vienna Conference on Human Rights, and then to incorporate a women's human rights framework in, and thereby transform, the consensus documents that emerged from the 1994 International Conference on Population and Development in Cairo, the 1995 World Summit on Social Development, and the 1995 Fourth World Conference on Women in Beijing. For example, the Vienna document condemned "systematic rape", and called for the elimination of violence and discrimination against women in public and private life as a priority matter, as well as the mainstreaming of gender in the human rights system. ${ }^{1}$ The Beijing Declaration and Platform for Action elaborated on the principle that "women's rights are human rights"; named, among others, "rape, including systematic rape, sexual slavery and forced pregancy" as particularly egregious humanitarian law violations; and called for gender balance among judges and other personnel in judicial institutions, including the ad hoc tribunals ${ }^{2}$.

The gains of which I will speak today are the product of all these initiatives, which were successful because they emanated from

1 The Women's Caucus is now known as the Women's Caucus for Gender Justice in recognition of the fact that the International Criminal Court [[[hereinafter ICC] is only one mechanism of gender justice. The caucus can be contacted through its Web site: <http://www.iccwomen.com>.

2 World Conference on Human Rights: Vienna Declaration and Programme of Action, 12 July 1993, UN Doc. A/CONF.157/23 at paras. 18, 28-30. 
a global mobilization of women, asserting that women's rights are human rights, that human rights (i.e. political, civil, social, and economic rights and the right to women-and human-centred sustainable development) are indivisible, and that impunity for gender crimes and acceptance of discrimination must end. Through mobilization, women's movements have become a force to be reckoned with internationally, despite the desperate and concerted efforts of right wing religious forces to block our progress and the reluctance of others to accept or recognize the need to make gender-inclusiveness a priority. The interrelationship between mobilization at every level and international legal change exemplifies the basic principle that human rights, like law itself, are not autonomous, but rise and fall based on the course and strength of peoples' movements and the popular and political pressure and cultural change they generate.

This last decade has indeed been historic in that there has been significant progress in transforming the discourse on a policy level. In the arena of international criminal law, there has been significant progress in eliminating the privatization of, and impunity for, gender crimes. For the first time, there have been steps to recognize women as full subjects of human rights and international criminal justice. Irwin Cotler told me that he was torn between placing me on this panel or the next one on the revolution in international criminal law, and suggested that I should declare myself part of both. I am happy to be the bridge, as I believe that gender justice which is among the most vehemently resisted aspects of international criminal law is both profoundly revolutionary and one of the ultimate tests of universal justice. In my brief remarks today, I will identify the major goals and achievements in this areaat the same time as I highlight the role of NGOs in the process of legal change- making, a subject too often neglected in academic settings.

\section{B. DISCUSSION}

\section{The Traditional Approach: Past and Present}

Before the 1990s, sexual violence in war was, with rare exception, largely invisible. If not invisible, it was trivialized; if not trivialized, it was considered a private matter or justified as an inevitable by-product of war, the necessary reward for the fighting men. The Leiber Code, drafted to regulate the Union army during the American Civil War, identified rape as a capital offence. Otherwise, if condemned, as rape was in the Hague Convention of 1907 and the Geneva Conventions, it was implicitly so, categorized as an offence against "family honour and rights" or as "outrages against personal dignity" or "humiliating and degrading treatment". The Fourth Geneva Convention called for "protection against [rape as an] ... attack on their honour," but rape was not treated as violence, and was therefore not named in the list of "grave breaches" subject to the universal obligation to prosecute. In 1977 the Protocols to the Geneva Conventions mentioned "rape, forced prostitution and any other form of indecent assault," but only as "humiliating and degrading treatment", a characterization that reinforced the secondary importance as well as the shame and stigma of the victimized women. The offence was against male dignity and honour, or national or ethnic honour. In this scenario, women were the object of a shaming attack, the property or objects of others, needing protection perhaps, but not the subjects of rights. Two examples illustrate this point, one from over fifty years ago, one from today. 


\section{Sexual Slavery: The "Comfort" Women}

As my first example, both the postWorld War II International Military Tribunals failed to adequately prosecute rape and sexual violence. Rape was not named in either charter or charged as a separate offence. Though listed as a crime against humanity in the Allied Local Council Law No. 10, under which intermediate-ranking Nazi war criminals were prosecuted, rape was never actually charged. In the Far East Tribunal, evidence of rape was part of the evidence of Japan's crimes against humanity. But the tribunal ignored the abduction and deception of over two hundred thousand girls and young women of non-Japanese origin from Japanese occupied territories and their transport to "comfort stations", now understood as rape camps. Euphemized as "comfort women", they were made to follow the troops on the battlefield and were subject to repeated rape, sometimes as often as forty times per day, as well as the domestic servicing of the Japanese troops. This "comfort"/slave system only came to public attention in the nineties, when aging and courageous survivors began to tell their stories, revealing the details and lifelong devastating effects of their enslavement, as well as of their exclusion from the halls of justice.

Why this official silence on sexual violence and on the unprecedented industrialization of sexual slavery, at least comparable in atrocity and systematization to the forced labour camps of Nazi Germany? There is still much to learn about the decision-making of that time and important work for historians. It is likely that rape was not explicitly prosecuted at Nuremberg, though it was a small part of the evidence ${ }^{3}$,

3 Fourth World Conference on Women: Beijing Declaration and Platform for Action, 17 October 1995, UN Doc. A/CONF.177/20; see e.g. paras. $132,224,142(b)$, respectively. See also Women's because some of the Allied troops were equally guilty of raping women an example of the banality of evil in militarized patriarchal culture.

With regard to the "comfort women" system, I confess that I originally assumed that it was effectively kept secret or invisible. But that is absurd. A conversation with a cousin, who was with the Allied forces when they took over Saipan, made the openness of this "secret" painfully clear. Upon arrival, he said, they learned that women were hiding in the island's caves. They found them desperate, some driven mad, many pregnant, terrified of the new invader. In other words, the nature, scope, and consequences of the system were no secret. Recent research in the military archives in Australia, notably that of Ustina Dolgopol, makes clear that the Allies were fully aware of this system, aware that women were taken and kept against their will, and aware that they were subjected to extreme sexual violence. They documented it through questioning both Japanese prisoners, U.S. soldiers, and the victimized women. Recent research by Japanese historians into Japan's archives has also revealed that the comfort women system, which began in 1932 and was expanded significantly in the Second World War, was authorized at the highest levels and minutely regulated ${ }^{4}$.

The comfort women slave system was designed to meet at least four articulated military needs: the need of their soldiers to "have sex"/rape to keep them fighting; the

Caucus for Gender Justice, The International Criminal Court: The Beijing Platform IN Action-Putting the ICC on the Beijing 5 Agenda (1999), online: Women's Caucus for Gender Justice < www.iccwomen.org/reports/bt5/index.htm> (date accessed: 7 October 2017).

4 Convention (IV) respecting the Laws and Customs of War on Land and its annex: Regulation concerning the Laws and Customs of War on Land, 18 October 1907, 3 Martens Nouveau Recueil (Ser. 3) 461, art. 46, 187 Consol. T.S. 227 (entered into force 26 January 1910). 
need to avoid antagonizing the local populations by preventing rape of women in the communities being occupied; the need to minimize sexually transmitted disease among the troops; and the need to keep rape from international scrutiny and outrage such as had occurred during the rape and killing spree that attended the conquest of Nanking ${ }^{5}$. In other words, the notion of women as the "booty" of war and the entitlement of fighting men was never in question.

By contrast, women's human rights activists have insisted, in many contexts, that rape is an atrocity whatever the purpose and whether or not widespread or systemic. The comfort women system illustrates, however, in a highly systematized and brutal way, that the rape of women, as booty or as the reward for the penultimate expression of the norm of masculinity, is also an integral part of the arsenal of war.

\section{Rape and Genocide in Rwanda: Invisibility and Inclusion}

The failure to prosecute sexual violence against women is not, however, a thing of the past. My second example concerns the initial failure to recognize and prosecute rape and sexual violence in Rwanda. Recall that genocide and other atrocities in Rwanda occurred after the widespread commission of rape and sexual violence in the former Yugoslavia had broken through media disinterest and captured world attention, and after rape had been listed as a crime against humanity in the statute of the ad hoc International Criminal Tribunal for the Former Yugoslavia 6 . Nonetheless, the media

5 Ibid., art. 147.

6 Prosecutor v. Jean Paul Akayesu, Amended Indictment, ICTR Trial Chamber (June 1997), Case No. ICTR-96-4-1, Indictment Counts 1, 2, 13-15 (International Criminal Tribunal for Rwanda, Trial Chamber), online: International Criminal Tribunal and other observers of the genocide in Rwanda did not report the massive and notorious rape of women during the Rwandan genocide. Rape was essentially invisible until nine months later, when a Belgian doctor publicized that women were presenting themselves in unusual numbers to bear the children of rape. Nor was it, thereafter, officially documented. That was left to the initiatives of two NGOs, African Rights and the Women's Project of Human Rights Watch? ${ }^{7}$.

It was common, at that time, to hear the assertion that genocide is killing, not rape, and that the women who were raped and survived were lucky they were not dead. Indeed, Shattered Lives reported that " There is a widespread perception among the Tribunal investigators that rape is somehow a 'lesser' or 'incidental' crime not worth investigating." 8 So, notwithstanding the legal definition of genocide which clearly encompasses sexual violence, as discussed below, and documentation of the terrible personal and societal impact of rape, including women's view that rape left them wishing for death, the Prosecutor v. Jean Paul Akayesu case went to trial with no charges or evidence of rape, and with the prosecutor

for Rwanda <http://www.ictr.org> (date accessed: 13 September 2017).

7 Ibid. at para. 731; this indicates that rape and sexual violence violates art. II(b) of the Convention on the Prevention and Punishment of the Crime of Genocide, 9 December 1948, 78 U.N.T.S. 277, Can. T.S. 1949 No. 27 (entered into force 12 January 1951) [hereinafter Genocide Convention], and art. 2(2)(b) of the ICTR Statute, supra note 16, by causing serious bodily or mental harm to members of the group.

8 See P.V. Sellers, "The Context of Sexual Violence: Sexual Violence as Violations of International Humanitarian Law" in G.K. McDonald \& O. SmaakGoldman, eds., Substantive and Procedural Aspects of International Criminal Law, vol. 1 (The Hague: Kluwer Law International, 2017) 263. 
claiming that it was impossible to document rape because women wouldn't talk about it.

All that changed when Judge Navanethem Pillay, the only woman judge on the ICTR Trial Chamber hearing the case, pursued the inquiry with two of the women who were called by the prosecutor to testify to other crimes whether rape had occurred in the Taba Commune. Witness J stated that three Interahamwe raped her six-year-old daughter when they came to kill her father, and also that she had heard that young girls had been raped at the bureau communal, which was under the authority of the accused. Witness $\mathrm{H}$ revealed that she had been raped in a sorghum field and that she had seen other Tutsi women being raped. She also testified that she knew of other women raped either in the nearby fields or on the site of the bureau communal, and that the accused and other commune officers were present and should have prevented it.

Akayesu was a landmark: the first international conviction for genocide, the first judgment to recognize rape and sexual violence as constitutive acts of genocide, and the first to advance a broad definition of rape as a physical invasion of a sexual nature, freeing it from mechanical descriptions and required penetration of the vagina by the penis. The judgment also held that forced nudity is a form of inhumane treatment ${ }^{9}$, and it recognized that rape is a form of torture and noted the failure to charge it as such under the rubric of war crimes ${ }^{10}$.

With respect to the issue of rape and sexual violence as genocide, the Akayesu

9 R. Copelon, F. Gaer \& J. Green, Amicus Memorandum Re: Application for Deferral by the Republic of Germany in the Matter of Dusko Tadic also known by the Names Dusan "Dule" Tadic [unpublished].

10 U. Dolgopol, "Rape as a War Crime Mythology and History" in I.L. Sajor, ed., Common Grounds: Violence against Women in War and Armed Conflict Situations (Asian Center for Women's Human Rights, 1998) 122. judgment is important because it explains why rape and sexual violence "constitute genocide in the same way as any other act as long as they were committed with the specific intent to destroy, in whole or in part, a particular group, targeted as such." ${ }^{11}$ The judgment emphasizes the ethnic targeting produced by the sexualized representation of ethnic identity, such as Akayesu's statement "let us now see what the vagina of a Tutsi woman tastes like", ${ }^{12}$ and parenthetically notes here the notion of women as booty as itself an instrument of genocide. The judgment characterizes these crimes as infliction upon women of serious bodily and mental harm, as they were charged, ${ }_{1}^{13}$ and also as an "integral part of the process of destruction, specifically targeting Tutsi women and specifically contributing to their destruction and to the destruction of the Tutsi group as a whole ... - destruction of the spirit, of the will to live, and of life itself. ${ }^{14 "}$ It notes the close connection with killing--that death or the threat of death often accompanied the rape of women ${ }^{15}$.

Ironically, the evidence associated with rape and sexual violence provided some of the strongest evidence of genocide. By emphasizing the suffering imposed on the women as well as its role as a tool of their destruction and the destruction of the group,

11 See generally Y. Yoshiaki, Comfort Woman: Sexual Slavery in the Japanese Military during World War II, trans. S. O'Brien (New York: Columbia University Press, 1995).

12 See e.g. Y. Tanaka, "Rape and War: The Japanese Experience" in Sajor, supra note 10, 148 at 16566; Yoshiaki, ibid. at 49.

13 Akayesu, ibid. at paras. 731-32; this indicates that rape and sexual violence may also qualify under art. II(c) of the Genocide Convention, ibid., and art. 2(2)(c) of the ITCR Statute, ibid., as "deliberately inflicting on the group conditions of life calculated to bring about its physical destruction in whole or in part."

14 Akayesu, ibid. at para. 733.

15 Genocide Convention, supra note 32 , art. II(d); ICTR Statute, supra note 16, art. 2(2)(d). 
the Trial Chamber took a significant step in recognizing women both as subjects in themselves and as part of their ethnicity.

The reproductive motives and consequences of sexual violence may also satisfy other constituent acts of genocide, as provided by the Genocide Convention. Akayesu recognizes that the constituent act of preventing births within the group ${ }^{16}$ includes measures such as forced sterilization, abortion, or birth control, as well as forced pregnancy where, in patriarchal societies, that represents an effort to affect ethnic composition by imposing the enemy's ethnicity on the children of rape. ${ }^{17}$ Rape, with its potential to cause infertility or make sexual intercourse impossible, as well as its potential to render a woman psychologically or culturally unable to reproduce, may also qualify, as a measure intended to prevent births within the group.

At the same time, it is significant that Akayesu did not, as some had contended, emphasize the reproductive consequences as the hallmark of rape as a genocidal measure. Rather, rape and sexual violence are understood as instruments of genocide based primarily on the physical and psychological harm to the woman, and secondarily on the potential impact of this on the targeted community. To emphasize the reproductive impact on the community would threaten once again to reduce women to being simply the vehicles of the continuity of the targeted population. It would also tend toward a biological as opposed to socially constructed view of identity as the value intended to be protected by the concept of genocide.

16 See R. Copelon, "Recognizing the Egregious in the Everyday: Domestic Violence as Torture" (1994) 25 Col. Hum. Rts. L. Rev. 291.

17 Supra note 14; Report of the Secretary-General Pursuant to Paragraph 2 of the Security Council Resolution 808, UN SCOR, 48th Sess., UN Doc. S/25704 (1993) 10 at para. 40.

\section{Engendering} Jurisprudence: The ICTY

The Akayesu judgment is part of an historic process of mainstreaming gender in international jurisprudence in which the ad hoc International Criminal Tribunal for the Former Yugoslavia took the first, landmark steps. The women's human rights movement mobilized to support the election of women judges, and their presence has been critical on the ICTY, just as Judge Pillay has played a critical role in the ICTR. In the start-up period, the ICTY judges, under the tutelage of the two women judges, Judge Gabrielle Kirk McDonald and Judge Elisabeth OdioBenito, adopted, as part of the initial rules of evidence and procedure, evidentiary rules, such as Rule 96, to prevent harassment of and discrimination against victims and witnesses through admitting evidence of prior sexual conduct or permitting unexamined consent defences in sexual violence cases. The ICTY rules also authorize other protections of victims and witnesses, including protective measures at trial and the creation of a victims and witnesses unit. The open process of rule- making, in which NGOs and states were invited to make suggestions, enabled feminist groups to focus attention on these problems ${ }^{18}$.

As a result, the ICTY has built a very significant body of jurisprudence that recognizes rape and sexual violence as forms of egregious violence. The ICTR's Akayesu judgment contributed most significantly to this process in recognizing rape as an act of genocide where the requisite intent is proven, and in identifying rape as a form of torture and subtly chiding the ICTR prosecutors who had declined to charge it as such. The ad hoc tribunals' jurisprudence proved to be a most

18 J. Green et al., "Affecting the Rules for the Prosecution of Rape and Other Gender-Based Violence before the International Criminal Tribunal for the Former Yugoslavia: A Feminist Proposal and Critique" (1994) 5 Hastings Women's L.J. 171. 
important foundation for the codification of sexual violence as part of the substantive jurisdiction of the International Criminal Court. ${ }^{19}$

The practice before the tribunals also illuminated a number of issues of implementation arising out of advertent and inadvertent discriminatory treatment of women in the process, as well as the need for gender-sensitive protective measures for women victims and witnesses and reliable support to minimize the risks and potential retraumatization of testifying. Thus, for example, Tadic produced a landmark decision outlining the criteria for keeping the identities of witnesses confidential from the public and, under special circumstances, anonymous even to the defence. On these issues, several feminist amicus briefs were filed, largely supporting the OP's motion for protective measures $^{20}$. In Furundzija, the defence

19 Supra note 44 at paras. 108, 109.

20 See Prosecutor v. Gagovic et al., Indictment, ICTY Trial Chamber (26 June 1996), Case No. IT-9623/2 (International Criminal Tribunal for the Former Yugoslavia, Trial Chamber), online: United Nations <http:// www.un.org/icty/indictment/english/focii960626e.htm> (date accessed: 27 September 2017); see Counts 1, 3, 4, incorporating the facts alleged in paras. 5.3-5.7, for reference to rape as torture in the context of interrogation (ibid.); see also Counts 13, 15, 16, incorporating the facts alleged in paras. $6.6-6.11$, for reference to rape as torture, in the context of interrogation. See also Prosecutor v. Gojko Jankovic et al., Amended Indictment, ICTY Trial Chamber (7 October 1999), Case No. IT-96-23-PT (International Criminal Tribunal for the Former Yugoslavia, Trial Chamber), online: United Nations <http://www.un.org/icty/indictment/english/foclai991007e.htm> (date accessed: 4 October 2017); see Counts 45-48, incorporating the facts alleged in paras 8.1-8.7, for reference to enslavement. This followed upon the landmark decision of the InterAmerican Commission on Human Rights in its Report on the Situation of Human Rights in Haiti to recognize rape in non-prison or interrogation contexts as a form of torture (OR OEA/Ser.L/V/11.88/Doc. 10, rev. (1995) at paras. questioned the credibility of the raped woman on the ground that she suffered posttraumatic stress disorder ("PTSD"). After hearing experts and, I believe, unnecessarily permitting the defence to recall the witness, the chamber rejected the defence contention that PTSD renders a victim unreliable ${ }^{21}$. Again, the tribunal had the benefit of two feminist amicus briefs $^{22}$. In Celebici, the defence was inadvertently allowed to circumvent Rule 96 (prohibiting the introduction of prior sexual conduct evidence) in questioning the witness about a prior abortion. The chamber reaffirmed the rule upon a motion to expunge the testimony from the record ${ }^{23}$.

133, 134); see also Aydin v. Turkey, App. No. 23178/94 (1997), 25 Eur. H.R. Rep. 251 at 295-96.

21 Prosecutor v. Anto Furundzija, Judgment, ICTY Trial Chamber II (10 December 1998), Case. No. IT-95$17 / 1$ at paras. 163, 266 (International Criminal Tribunal for the Former Yugoslavia, Trial Chamber II), online: United Nations <http://www.un.org/icty/furundzija/trialc2/judgem ent/furtj981210e.htm> (date accessed: 24 September 2017) [hereinafter Furundzija].

22 See Prosecutor v. Zejnil Delalic, Judgment, ICTY Trial Chamber II (16 November 1998), Case No. IT-96-21 at paras. 480-96 (International Criminal Tribunal for the Former Yugoslavia, Trial Chamber II), online: United Nations <http://www.un.org/icty/celebici/trialc2/decisione/311096.htm> (date accessed: 24 September 2017).

23 Prosecutor v. Dusko Tadic, Decision of the Prosecutor's Motion Requesting Protective Measures for Victims and Witnesses, ICTY Trial Chamber (10 August 1995), Case No. IT-94-1 (International Criminal Tribunal for the Former Yugoslavia, Trial Chamber), online: United Nations $<$ http:// www.un.org.icty/tadic/trialcz/decisione/100895pm.htm> (date accessed: 27 September 2017). This opinion references the two amicus briefs at the outset: one amicus brief was filed by Prof. Christine Chinkin, Dean and Professor of International Law, University of Southampton, United Kingdom, and a joint brief was filed by Rhonda Copelon, Felice Gaer, Jennifer M. Green, and Sara Hossain on behalf of the Jacob Blaustein Institute for the Advancement of Human Rights of 
At the same time as the progressive gender jurisprudence of the ad hoc tribunals has been very significant, their defalcations in the realm of gender crimes, witness protection, and participation of the survivor communities have also illuminated some of the prerequisites of a fully gender-integrated process. For example, notwithstanding the landmark Akayesu judgment, the ICTR prosecutor has been slow to incorporate charges of sexual violence consistently and in accordance with their deserved gravity. There is an apparent absence of both a clear policy that gender is a priority concern and of a gender expert, with oversight authority, onsite. Issues of witness protection, the gendersensitivity of investigations, and community relations have been equally significant. Perhaps someday the integration of and respect for gender expertise will become routine, dispensing with the need for continued monitoring by feminist attorneys and activists. That day is still far off.

\section{The International Criminal Court: Codifying Gender Justice}

The existence of the ad hoc tribunals, the proliferation of wars, and the unseating of many brutal dictatorships in these last decades reignited the effort to create a permanent international criminal court. Feminists in different parts of the world recognized the existence of the ICC negotiations as an opportunity to codify the integration of gender in international criminal law, as well as work to ensure a court independent of the powerful nations, particularly the United States and the P5. This was the task assumed by the Women's Caucus for Gender Justice, created in 1997.

the American Jewish Committee, the Center for Constitutional Rights, the International Women's Human Rights Clinic, the Women Refugees Project of the Harvard Immigration and Refugee Program, and Cambridge and Somerville Legal Services (ibid.).
Women brought to the caucus many different experiences and perspectives. These were informed by regional diversity and a broad range of experience of advocacy in domestic courts and legislatures, meeting at international conferences, monitoring the ad hoc tribunals, and working with survivors of sexual violence.

Like the Women's Caucuses at the World Conferences, the ICC Women's Caucus met with two kinds of opposition. On the onehand, we faced increasingly fierce misogynist opposition from the Vatican, the islamist-oriented Arab League countries, and North American right wing groups such as the U.S.-based International Human Life Committee, the David M. Kennedy Center, and Canada's JMJ (Jesus, Mary and Joseph) Children's Fund and R.E.A.L. Women ${ }^{24}$. On the other hand, we also had to start from scratch with many delegates who did not see a need for a specific gender perspective and rued the time that introduction of our issues would take. Thanks to the expertise and commitment of a small group of delegates-both women and men--and the openness, albeit sometimes reluctant, of the overwhelming majority of delegates, the Statute of the International Criminal Court is a landmark. It has codified not only crimes of sexual and gender violence as part of the jurisdiction of the Court, but also a range of structures and procedures necessary to ensure that these crimes and those victimized by them will remain on the agenda and be properly treated in the process of justice. I am not going to canvass all the gender aspects of the Rome Statute, but rather will point out a few of the caucus's major goals and accomplishments.

As to the ICC's substantive jurisdiction over crimes, the Women's Caucus had two

2417 July 1998, UN Doc. No. A/CONF.183/9, 37 I.L.M. 9999 (not entered into force) [hereinafter Rome Statute]. 
goals. One was to codify explicitly a range of serious sexual violence crimes in order to ensure that they are always on the checklist and always understood as crimes in themselves. The second was to incorporate, as a principle, what had developed in the customary law and jurisprudence of the tribunals, that sexual violence must be seen as part of, and encompassed by, other recognized egregious forms of violence, such as torture, enslavement, genocide, and inhumane treatment ${ }^{25}$.

But, many asked, why both? If the sexual violence crimes are listed, and therefore squarely on the prosecutor's checklist, why does gender integration matter? The answer is that despite all the public hand-wringing about rape, history teaches that there is an almost inevitable tendency for crimes that are seen simply or primarily as crimes against women to be treated as of secondary importance. It makes a difference, to the elements that must be proved, to the penalty imposed, and to the larger cultural understanding of violence against women, to treat rape as torture rather than humiliation. So we needed to insist, as a matter of the principle of nondiscrimination, that sexual violence be treated as constituting any of the recognized crimes so long as it met their elements, at the same time as it was necessary to name the sexual violence crimes specifically. And the Rome Statute represents a significant step in this direction.

25 Ibid. at para. 107; see Amicus Curiae Brief on Protective Measures for Victims or Witnesses of Sexual Violence and Other Traumatic Events, Submitted by the Center for Civil and Human Rights, Notre Dame Law School [unpublished]; Amicus Curiae Brief Respecting the Decision and Order of the Tribunal of 16 July 1998 Requesting That the Tribunal Reconsider Its Decision Having Regard to the Rights of Witness A to the Equality, Privacy, and Security of Person and to Representation by Counsel, Submitted by Joanna Birenbaum et al [unpublished].
Article 8 of the Rome Statute, which delineates the jurisdiction of the Court over war crimes in international and internal war, explicitly lists "rape, sexual slavery, enforced prostitution, forced pregnancy ... enforced sterilization or any other form of sexual violence also constituting" either "grave breaches" or violations of Common Article 3 of the Geneva Conventions ${ }^{26}$. This expanded significantly on, as well as removed, the moralistic element from the range of previously recognized war crimes, i.e. rape, enforced prostitution, and other indecent assault. The "also constituting" language was primarily intended to codify the principle of gender integration and to make clear that sexual violence is a grave breach, equivalent in gravity to other crimes subject to universal jurisdiction. Indeed, in an historic debate at the December PrepCom, the delegates assembled rejected, with one opposition and two abstentions, placing rape and sexual violence under the rubric of humiliating and degrading treatment rather than that of grave breaches and serious violations. In this list of crimes, the definition of forced pregnancy was the last to be resolved, as the Vatican, supported by the Islamic countries, sought unsuccessfully to eliminate any suggestion that obstructing a woman's access to abortion could be a crime ${ }^{27}$.

26 Ibid., arts. 8(2)(b)(xxii), 8(2)(e)(vi).

27 Prosecutor v. Zejnil Delalic, Decision on the Prosecution's Motion for the Redaction of the Public Record, ICTY Trial Chamber (5 June 1997), Case No. IT-96-21 (International Criminal Tribunal for the Former Yugoslavia, Trial Chamber), online: United Nations <http:// www.un.org/icty/celebici/trialc2/decision-

e/60605MS2.htm> (date accessed: 24 September 2017). For fuller treatment of the tribunals' jurisprudence affecting the prosecution of gender crimes, see K.D. Askin, "Sexual Violence in Decisions and Indictments of the Yugoslav and Rwandan Tribunals: Current Status" (1999) 93 A.J.I.L. 97

GENDER: INTEGRATING CRIMES AGAINST WOMEN INTO INTERNATIONAL CRIMINAL LAW Mohammad Irfan 
Article 7, delineating crimes against humanity, adopts the same list of sexual and reproductive violence crimes, qualifying them, at the last minute, by the phrase "of comparable gravity", which logically calls for comparison with all crimes against humanity. The crime against humanity of enslavement explicitly includes trafficking, with particular but not exclusive attention to women and girls.

Among the most contentious issues was the expansion of the crime of persecution beyond the previously accepted grounds of race, ethnicity, nationality, religion, and politics to include persecution based on "gender" as well as against other social groups. The statute incorporates a definition of "gender", and defines other grounds as those "that are universally recognized as impermissible under international law." I'll return to this in a minute. In a futile effort by the United States to exclude institutionalized discrimination, the crime of persecution also requires proof of an act of violence, such as killing, torture, or inhumane treatment, or a war crime or genocide.

As an overarching matter, the chapeau to crimes against humanity recognizes that crimes of this dimension can be perpetrated against any civilian population, in time of peace as well as war, and by private as well as state actors. This is particularly important for women, as we are most often the victims of non-state as opposed to state violence in civil society as well as war. The statute does not adopt the full range of crimes against humanity under international law, however, insofar as it compromises the customary threshold requirement that the crimes be "widespread or systematic". In a definitional section, the Rome Statute explains that a policy to commit a widespread or systematic attack must involve relation to a state or organizational policy and multiple acts. This should not be too troublesome in the future, so long as, consistent with international law, the failure to prevent qualifies as policy.

\section{CONCLUSION}

We must, anticipate significant opposition to applying crimes against humanity to the gender crimes of everyday life, but it is important to press that point. We must continually make the connection between gender violence and persecution in war and conflict and, as Eleanor Roosevelt said of human rights, "in the small places close to home," if we are to counter the culture of male entitlement to use women as property. In other words, if the ICC is successful, it will function not only to prevent atrocities in identified conflict situations, but also to sharpen the popular understanding of the atrociousness of sexual and gender violence and persecution and the relation between torture in intimate relationships and atrocities in the context of war. Also, with regard to the problem that judicial institutions are called into action after the fact, it is important to bear in mind the essential relationship between political, economic, social inequality, including gender inequality, and violence in all contexts.

In addition to looking at historical and immediate signs of violence, it is necessary to look at basic economic and political conditions that generate or provide the ground for manipulation of insecurity, desperation, and rage into hatred and violence. These include issues of gender inequality as well as economic issues, and particularly the impact of economic and media globalization on those it colonizes. It was not irrelevant to the genocide in Rwanda that Hutus were stirred up to attack Tutsis because there had been a huge inflation and they were told that the Tutsi would take their cows. It was not irrelevant that Tutsi women were propagandized as treacherous and sexually enticing targets. We cannot prepare the ground for peace and security and exclude 
from consideration either globalization policies that breed economic insecurity and insecurity about identity, or the role of patriarchal and misogynist culture in everyday life.

\section{BIBLIOGRAPHY}

Akayesu, ibid. at paras. 731-32; this indicates that rape and sexual violence may also qualify under art. II(c) of the Genocide Convention, ibid., and art. 2(2)(c) of the ITCR Statute, ibid., as "deliberately inflicting on the group conditions of life calculated to bring about its physical destruction in whole or in part."

Amicus Curiae Brief on Protective Measures for Victims or Witnesses of Sexual Violence and Other Traumatic Events, Submitted by the Center for Civil and Human Rights, Notre Dame Law School [unpublished]; Amicus Curiae Brief Respecting the Decision and Order of the Tribunal of 16 July 1998 Requesting That the Tribunal Reconsider Its Decision Having Regard to the Rights of Witness A to the Equality, Privacy, and Security of Person and to Representation by Counsel, Submitted by Joanna Birenbaum et al [unpublished].

C. Walsh, "Witness Protection, Gender and the ICTR", online: International Centre for Human Rights and Democratic Development <http:// www.ichrdd.ca/111/english/commdoc/publications/womtrirw.html>

Convention (IV) respecting the Laws and Customs of War on Land and its annex: Regulation concerning the Laws and Customs of War on Land, 18 October 1907, 3 Martens Nouveau Recueil (Ser. 3) 461, art. 46, 187 Consol. T.S. 227 (entered into force 26 January 1910).

For fuller discussion of the history and significance of characterizing rape as torture, see $\mathrm{R}$. Copelon, "Surfacing Gender: Re- Engraving Crimes against Women in Humanitarian Law" (1994) 5 Hastings Women's L.J. 243 at 249-57; D.Q. Thomas \& R.E. Regan, "Rape in War: Challenging the Tradition of Impunity" (1994) 14 SAIS Rev. 81; T. Meron, "Rape as a Crime under International Humanitarian Law" (1993) 87 A.J.I.L. 424; D. Blatt, "Recognizing Rape as a Method of Torture" (1992) 19 N.Y.U. Rev. L. \& Soc. Change 821.

Fourth World Conference on Women: Beijing Declaration and Platform for Action, 17 October 1995, UN Doc. A/CONF.177/20; see e.g. paras. 132, 224, 142(b), respectively. See also Women's Caucus for Gender Justice, The International Criminal Court: The Beijing Platform IN Action--Putting the ICC on the Beijing 5 Agenda (1999)

Genocide Convention, supra note 32, art. II(d); ICTR Statute, supra note 16, art. 2(2)(d).

J. Green et al., "Affecting the Rules for the Prosecution of Rape and Other Gender-Based Violence before the International Criminal Tribunal for the Former Yugoslavia: A Feminist Proposal and Critique" (1994) 5 Hastings Women's L.J. 171.

P.V. Sellers, "The Context of Sexual Violence: Sexual Violence as Violations of International Humanitarian Law" in G.K. McDonald \& O. Smaak- Goldman, eds., Substantive and Procedural Aspects of International Criminal Law, vol. 1 (The Hague: Kluwer Law International, 2017) 263.

Prosecutor v. Anto Furundzija, Judgment, ICTY Trial Chamber II (10 December 1998), Case. No. IT-95-17/1 at paras. 163, 266 (International Criminal Tribunal for the Former Yugoslavia, Trial Chamber II), online: United Nations <http://www.un.org/icty/furundzija/trialc2/judgement/furtj981210e.htm> (date accessed: 24 September 2017) [hereinafter Furundzija]. 
Prosecutor v. Dusko Tadic, Decision of the Prosecutor's Motion Requesting Protective Measures for Victims and Witnesses, ICTY Trial Chamber (10 August 1995), Case No. IT-94-1 (International Criminal Tribunal for the Former Yugoslavia, Trial Chamber)

Prosecutor v. Jean Paul Akayesu, Amended Indictment, ICTR Trial Chamber (June 1997), Case No. ICTR-96-4-1, Indictment Counts 1, 2, 13-15 (International Criminal Tribunal for Rwanda, Trial Chamber), online: International Criminal Tribunal for Rwanda <http://www.ictr.org> (date accessed: 13 September 2017).

Prosecutor v. Zejnil Delalic, Decision on the Prosecution's Motion for the Redaction of the Public Record, ICTY Trial Chamber (5 June 1997), Case No. IT-96-21

R. Copelon, "Recognizing the Egregious in the Everyday: Domestic Violence as Torture" (1994) 25 Col. Hum. Rts. L. Rev. 291.

R. Copelon, F. Gaer \& J. Green, Amicus Memorandum Re: Application for Deferral by the Republic of Germany in the Matter of Dusko Tadic also known by the Names Dusan "Dule" Tadic [unpublished].

Supra note 14; Report of the Secretary-General Pursuant to Paragraph 2 of the Security Council Resolution 808, UN SCOR, 48th Sess., UN Doc. S/25704 (1993) 10 at para. 40.

U. Dolgopol, "Rape as a War Crime--Mythology and History" in I.L. Sajor, ed., Common Grounds: Violence against Women in War and Armed Conflict Situations (Asian Center for Women's Human Rights, 1998) 122.

World Conference on Human Rights: Vienna Declaration and Programme of Action, 12 July 1993, UN Doc. A/CONF.157/23 at paras. 18, 28-30.

Y. Tanaka, "Rape and War: The Japanese Experience" in Sajor, supra note 10, 148 at 165-66; Yoshiaki, ibid. at 49.

Y. Yoshiaki, Comfort Woman: Sexual Slavery in the Japanese Military during World War II, trans. S. O'Brien (New York: Columbia University Press, 1995). 